\title{
EFFECT OF BIOSTIMULATION BY BULL EXPOSURE ON RECOVERY OF OVARIAN ACTIVITY AND REPRODUCTIVE ASPECTS DURING THE POSTPARTUM PERIOD OF EGYPTIAN BALADI CATTLE
}

\author{
A.I. Damarany \\ Department of Animal and Poultry Production Faculty of Agriculture and Natural Resources, Aswan \\ University, Egypt
}

Received: 10/6/2019

Accepted: 26/6/2019

\section{SUMMARY}

The current research aims to investigate the effects of biostimulation on recovery of ovarian activity and reproductive aspects during postpartum period of Baladi cattle. A total number of thirty-six of Baladi cattle was used in this study during the post-partum period. The cows were divided into two equal groups; the first group was exposed to teaser bull and the second group as a control. The results indicated that the percentage of cows resumed ovarian activity during the post-partum period was 72.2 and $38.8 \%$ in cows exposed to bull and without presence of the bull respectively $(P<0.05)$. The interval from calving to the first ovulation during the post-partum period was significantly lower $(P<0.05)$ in cows of the first group than cows of the second group by about seventeen days. The interval from calving to the first estrus post-partum was significantly $(P<0.05)$ longer by fifteen days in cows that not exposed to bull than in cows exposed to bull. The proportion of quiet ovulation was significantly $(P<0.05)$ lower $(30.8 \%)$ in cows that exposed to bull compared to cows that not exposed to bull $(42.9 \%)$. The percentage of anestrous cases was significantly $(P<0.05)$ lower $(27.8 \%)$ in cows that exposed to bull compared with cows that not exposed to bull (61.2\%). First service interval post-partum was significantly $(P<0.05)$ lower $(70.7 \pm 18.7 d)$ in treated cows than in cows of the control group $(85.8 \pm 10.4 d)$. The interval from calving to conception was significantly $(P<0.05)$ lower $(91.7 \pm 18.5 d)$ in cows exposed to bull than cows of the control group (110.5 \pm 8.7 d). Number of service per conception was lower $(1.8 \pm 0.4$ service) in treated cows than cows of control (2.5 \pm 0.6 services). Conception rate in cows that exposed to bull during the post-partum period was higher $(50 \%)(P<0.05)$, compared to cows not exposed to bull with recorded less percentage (22.2\%). Estrus signs under the experiment were more manifested in cows that exposed to bull compared to the control group. In conclusion, the results of this research elucidated the beneficial effect of presence of bull with cows and resumption of ovarian activity and improving the reproductive aspects of Baladi cattle during the post-partum period.

\section{Key words: Biostimulation, ovarian activity, reproductive aspects, Baladi cattle}

\section{INTRODUCTION}

Biostimulation is one of the methods that used for motivation of the cows to resume ovarian activity. Martin et al. (2004) and Martin (2009), Socio-sexual stimuli became more focused through recent years. Biostimulation depends on the pheromones execreted from the bull, which plays an effective role in cattle behavior and reproductive processes Custer et al. (1990), Fernandez et al. (1993) and Shipka and Ellis (1998). In cattle, cutaneous glands, urine or feces are the major source of pheromones that intermediate the bio-stimulatory effect of bulls on resumption of ovarian activity in cows and accelerate the onset of puberty in heifers (Fike et al., 1996; Rekwot et al., 2001 and Tauck and Berardinelli, 2007). Biostimulatory effect of bulls is mediated by secretion of pheromones into the environment through excretory products of bull (Berardinelli and Joshi, 2005). Exposure of cows to bull $24 \mathrm{hrs}$ daily lead to hasten resumption of ovarian activity in anestrous suckled cows during the postpartum period (Tauck et al., 2006). Kerketta et al. (2017) reported that the bio-stimulation technique offers an effective tool and practical way to improve reproductive efficiency in cattle. Many investigations concerned with the effects of biostimulation on resumption of ovarian activity were reported (Landaeta-Hernández et al., 2013; Akhtar et al., 2015 and Zaidi and Anwar, 2018). Recently, many researchers (Mat, 2013; Silva Filho et al., 2015 and Ungerfeld, 2018) suggested that there is a positive effect of bio-stimulation on reproductive efficiency in post-partum period. The present investigation aim to, study the effect of bull exposure to Egyptian Baladi cows during the postpartum period on recovery of ovarian activity and reproductive aspects.

\section{MATERIALS AND METHODS}

\section{Experimental design:}

Thirty-six of Baladi cows were divided into two groups ( $\mathrm{n}=18$ cows for each group). The first group was exposed to bull daily after calving immediately. The second group was non- exposed to bull used as a control and the round of exposure to bull was done for a duration of 120 days post-partum all day. 
Location of farm and weather conditions :

This work was carried out in Aswan governorate. The farm of cows is located at Nasser El-Nubba city (32', 31' 23" East and 22, 28'09" North). Ambient temperature and relative humidity during the hot months are presented in Table (1). Temperature humidity index (THI) estimated according to the formula proposed by Mader et al. (2006):
THI $=(0.8 \times \mathrm{T} \max \mathrm{db})+[(\mathrm{RH} / 100) \times(\mathrm{T} \max \mathrm{db}$ $-14.4)]+46.4$

Temperature-humidity index $(\mathrm{THI})=0.8 \mathrm{x}$ ambient temperature $+[(\%$ relative humidity) 100$) \times$ (ambient temperature -14.4$)]+46.4$

Table 1. The ambient temperature $\left(\mathrm{C}^{\circ}\right)$, relative humidity $(\%)$ and temperature humidity index throughout the hot months

\begin{tabular}{lrrrrr}
\hline \multirow{2}{*}{ Hot months } & \multicolumn{2}{c}{$\begin{array}{c}\text { Average } \\
\text { Ambient Temperature }\left(\mathbf{C}^{\circ}\right)\end{array}$} & \multirow{2}{*}{$\begin{array}{c}\text { Average } \\
\text { Relative Humidity (RH\%) }\end{array}$} & THI \\
\cline { 2 - 3 } & Min & Max & 34.0 & 17 & 76.9 \\
April & 20.1 & 40.7 & 16 & 83.2 \\
May & 22.6 & 41.4 & 16 & 83.8 \\
June & 25.3 & 41.2 & 17 & 83.9 \\
July & 26.2 & 41.0 & 18 & 83.9 \\
August & 26.0 & 38.4 & 20 & 81.9 \\
September & 23.8 & & & \\
\hline
\end{tabular}

\section{Animals feeding and management:}

The cows were used after calving immediately. Specifications of experimental cows are presented in Table (2). Cows raised in traditional farm as semishaded yards. In addition to concentrate ration (corn grains and wheat bran), animals were offered alfa- alfa, hay wheat, corn fodder during the experimental period. All cows were kept under the same environmental and managerial conditions according the farm routine work.

Table 2 . Specifications (Mean \pm SE) of cows exposed or not exposed to bull

\begin{tabular}{lccc}
\hline Groups & Body weight (kg) & Age (years) & Parity \\
\hline Bull-exposed (BE) $(\mathrm{n}=18)$ & $376.83 \pm 16.47$ & $6.36 \pm 2.42$ & $4.78 \pm 1.86$ \\
Not exposed (NE) $(\mathrm{n}=18)$ & $378.72 \pm 14.92$ & $5.98 \pm 2.31$ & $4.11 \pm 1.53$ \\
Overall $(\mathrm{n}=36)$ & $377.78 \pm 15.52$ & $6.17 \pm 2.34$ & $4.44 \pm 1.71$ \\
\hline
\end{tabular}

\section{Heat detection and pregnancy diagnosis:}

Daily visual observation of cows was executed in the morning at 6:0 am and night and 18:0 pm. Once any sexual behavior signs demonstrated cows considered in estrus. The cows were inseminated naturally once displaying standing signs of heat. Diagnosis of pregnancy was established by rectal palpation 60 days post-mating) as described by Arthur (1964).

Conception rate: calculated as the percentage of cows, which conceived from the first mating postpartum

Conception rate $=$ Number of pregnant cows/Total number of mated cows x 100 .

\section{Ovarian activity:}

The ovarian activity was established by plasma progesterone concentration (once a week sampling), when the plasma progesterone concentration rise above the basal line $(1 \mathrm{ng} / \mathrm{ml})$ blood, so the ovary started its activity. Besides that, rectal palpation was performed for detecting the corpus luteum on the ovary in weekly basis.

\section{Analysis of hormones:}

Blood samples were collected at estrus, day 7, 14 and 21 after mating in heparinized tubes from the jugular vein. Samples were centrifuged at $3000 \mathrm{rpm}$ for 15 minutes for plasma harvesting. Plasma was separated and stored at $-18{ }^{\circ} \mathrm{C}$ until the time of analysis, progesterone (P4) hormone was determined using radioimmunoassay kit (Immunotech, France). Sensitivity value reported to be according to manufacturer information. The intra- and inter-assay variation coefficients were 6.3 and $11.4 \%$, respectively.

\section{Statistical analysis:}

The statistical design included one factor (effect of exposure to bull), the analysis was performed confirmed using SAS (2002). The following model was used:

\section{Where:}

$$
\mathbf{Y}_{\mathrm{ij}}=\boldsymbol{\mu}+\mathbf{T}_{\mathrm{i}}+\mathbf{e}_{\mathrm{ij}}
$$

$\mathbf{Y}_{\mathbf{i j}}=$ the observation trait

$\boldsymbol{\mu}=$ overall mean

$\mathbf{T}_{\mathbf{i}}=$ effect of exposure to bull (treatment $=1$, control=2)

$\mathbf{e}_{\mathrm{ij}}=$ experimental error

Duncan's Multiple Range test (Duncan, 1955) was used to test the significance of the differences between means. Chi Square was performed.

\section{RESULTS AND DISCUSSION}

\section{Effect of exposure to bull on resumption of ovarian} activity of Egyptian Baladi cattle:

Figure (1) shows the percentage of cows resumed ovarian activity post-partum, which was 72.2 and 
$38.8 \%$ in cows exposed to bull and not exposed to bull, respectively. There was a significant $(P<0.05)$ difference between both groups. The obtained result is in agreement with that reported by LandaetaHernández et al. (2008) and Tauck et al. (2010) who found that proportion of cows resumed ovarian activity was higher (100 and 60\%) in cows exposed to bull than those not exposed to bull ( 80 and $10 \%$ ), respectively. Bolanios et al. (1998) showed that the percentage of cows repeated ovarian activity was greater in cows exposed to a bull $(57 \%)$ than in unexposed cows (7\%). The proportion of cows resumed ovarian activity was higher in cows that exposed to a bull $(25.4 \%)$ than those not exposed to bull $(14.7 \%)$ at sixteen days after calving. The percentage of cows repeated ovarian activity was higher in cows that exposed to a bull (53.7\%) compared to that cows not exposed to bull $(35.3 \%)$ during eighty days post-partum (Rekwot et al., 2000b).

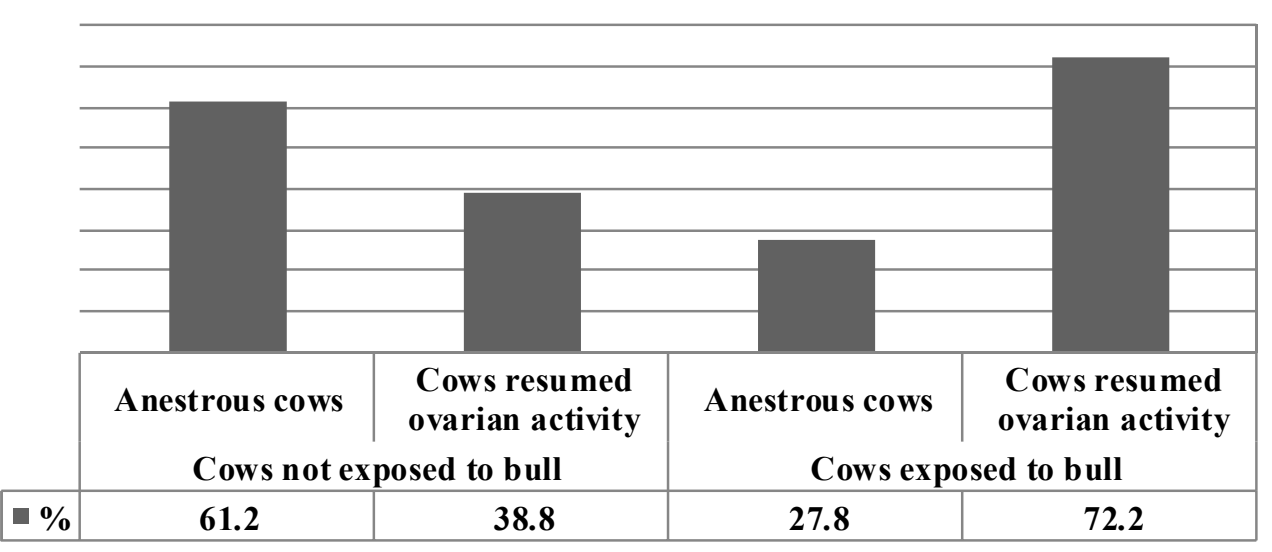

Figure (1). Percentage of cows resumed ovarian activity of Baladi cows exposed and not exposed to bull during 120 days post-partum period

The interval from calving to the first ovulation post-partum was significantly lower $(P<0.05)$ in cows exposed to bull than those not exposed to bull by about seventeen days (Table 3 ). The present results are in correspondence with those reported by (Landaeta-Hernández et al., 2008; Tauck et al., 2010 and Akhtar et al., 2015) who estimated the interval from calving to the first ovulation to be lower in cows exposed to bull ranging between (39.7 -87.7 days) than those not exposed to bull (49.7- 101.2 days). Similar trend was reported by Naasz and Miller (1987) who showed that the interval from calving to resumption of ovarian activity was lower in cows exposure to bull (47.2 days) compared with those not exposed to bull (71.4 days). Additionally, Naasz and Miller (1990) found that repeated estrus occurred sixteen days earlier for cows exposed to bull compared to those not exposed to bull. Recently Zaidi and Anwar (2018) investigated that biostimulation by exposing the Nili-Ravi buffaloes to bull for 24 hour daily accelerate the repetition of postpartum ovarian activity. In addition, Crowe et al. (2014) found that late repetition of ovulation in cows is fixedly due to a GnRH-mediated lack of LH pulse frequency.

Table 3. Effect of exposure to bull on resumption of ovarian activity during 120 days post-partum of Egyptian Baladi cattle

\begin{tabular}{|l|c|c|}
\hline \multicolumn{1}{|c|}{ Items } & Exposure to bull & Non- exposure to bull \\
\hline No. of cases & 18 & 18 \\
\hline Number of cows resumption of ovarian activity ${ }^{1}$ & 13 & 7 \\
\hline Percentage of cows resumption of ovarian activity (\%) $^{\mathrm{b}}$ & $72.2^{\mathrm{a}}$ & $38.8^{\mathrm{b}}$ \\
\hline $1^{\text {st }}$ Ovulation post-partum (days) & $63.9^{\mathrm{a}} \pm 21.5$ & $80.7^{\mathrm{b}} \pm 15.1$ \\
\hline $1^{\text {st }}$ Estrus post-partum (days) & $70.7^{\mathrm{a}} \pm 18.7(9)$ & $85.8^{\mathrm{b}_{\mathrm{b}}} \pm 10.4(4)$ \\
\hline Quiet ovulation (\%) & $30.8^{\mathrm{a}}(4)$ & $42.9^{\mathrm{b}}(3)$ \\
\hline Anestrous cases (\%) & $27.8^{\mathrm{a}}(5)$ & $61.2^{\mathrm{b}}(11)$ \\
\hline
\end{tabular}

$a, b$ : values within the same row having different superscripts are significantly different at $(P<0.05)$

1-Resumption of ovarian activity during 120 days post-partum

The interval from calving to the first estrus postpartum $(70.7 \pm 18.7)$ and $(85.8 \pm 10.4)$ days, in cows exposed and no-exposed to bull, respectively (Table $3)$. This interval was significantly $(P<0.05)$ longer by fifteen days in cows that not exposed to bull. The present result is in agreement with that reported by Naasz and Miller (1990) and Landaeta-Hernández et al. (2008) who found that the intervals from calving 
to first estrus was longer (59.9 and 58.3 days) in cows that not exposed to bull than those exposed to bull (38.1 and 42.2 days), respectively. Similar trend was reported by Gokuldas et al. (2010) who found that intervals from calving to first estrus was lower in cows exposed to bull (57.7 day) compared with those not exposed to bull (71.3 day). Monje et al. (1983) showed that cows that exposed to bull returned early to estrus by 14 day compared with cows that no exposed to bull. In addition, Burns and Spitzer (1992) found that the interval from calving to estrus declined in cows that exposed to bulls.
The proportion of quiet ovulation was significantly $(P<0.05)$, lower $(30.8 \%)$ in cows that exposure to bull compared with those not exposed to bull $(42.9 \%)$ (Figure, 2). The present result is in conformity with that reported by Shipka and Ellis (1998) and Gokuldas et al. (2010) who found that the quiet ovulation was lower in cows that exposed to bull ( 24.0 and $18.8 \%$ ) compared with those not exposed to bull (35.7 and 50.0\%), respectively. Significantly, decline percentage of quiet ovulation in cows exposed to bull (22\%) was found in contrast with $(89 \%)$ in cows that not exposed to bull (Alberio et al., 1987).

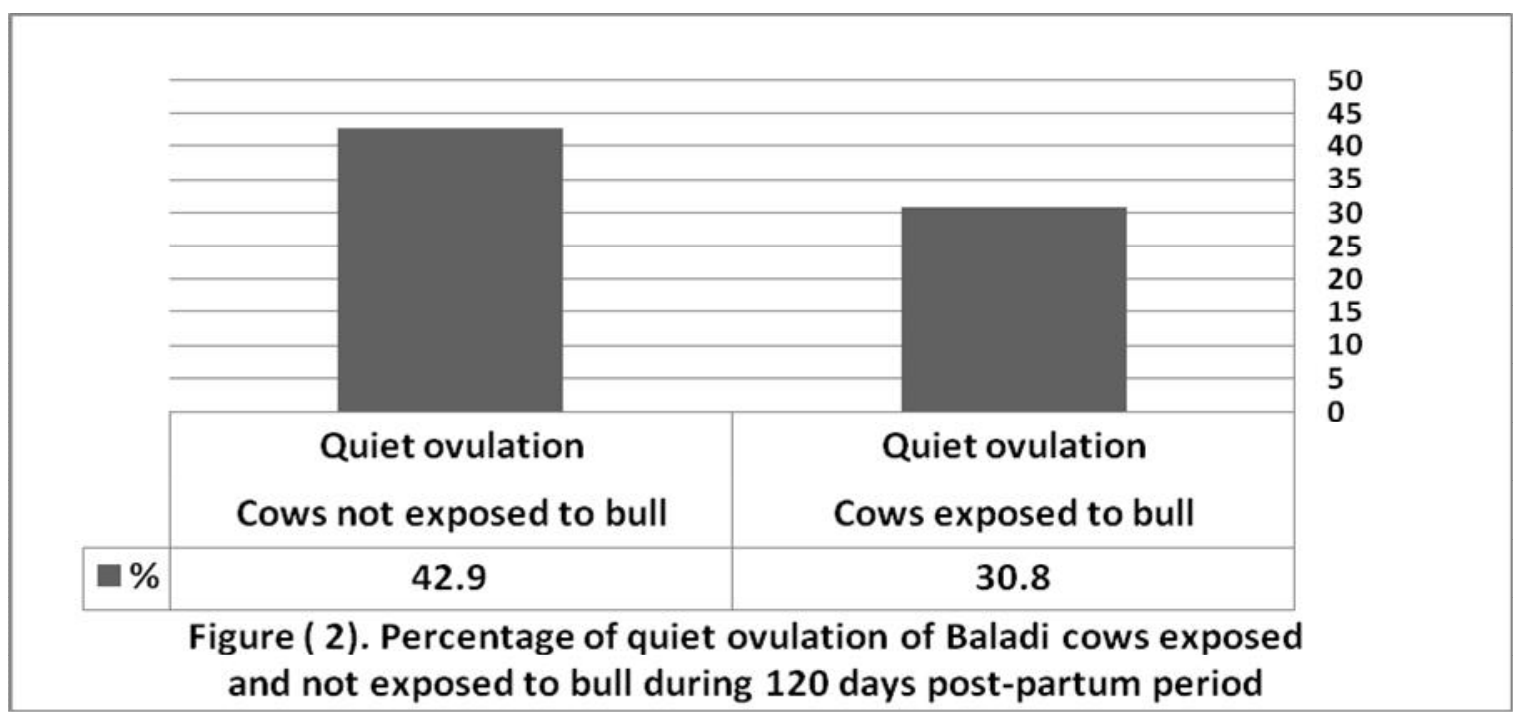

The percentage of anestrous cases was significantly $(P<0.05)$ lower $(27.8 \%)$ in cows that exposed to bull compared with cows that not exposed to bull $(61.2 \%)$, (Figure, 1). The present result is in agreement with that reported by Landaeta-Hernández et al. (2008) who found that lower anestrous cases were observed in cows that exposed to bull $(3 \%)$ versus to $(20 \%)$ in cows that not exposed to bull. Similar trend was reported by Berardinelli and Joshi (2005), Landaeta-Hernández et al. (2006) and Miller and Ungerfeld (2008) who found that exposure of cows to bulls decline postpartum anestrous interval. In addition, Zalesky et al. (1984); Alberio et al. (1987) and Custer et al. (1990) indicated that presence of a bull with cows during post-partum period decreases occurrence of anestrus cases. Introduction of bull with cows throughout postpartum period maybe due to increase in LH pulse secretion in postpartum cows (Fernandez et al., 1996 and Tauck et al., 2010) and anestrous heifers (Fiol and Ungerfeld, 2016). Similar observation was found by Kerketta et al. (2017) who reported that biostimulation maybe can effects on reproductive activity through the hypothalamic system that produce pulses of (GnRH). Berardinelli and Tauck (2007) and Miller and Ungerfeld (2008) suggested that the biostimulatory effects of bull exposure on cows initiated a favorable response by influencing regulation of hormone and ovarian activity.

\footnotetext{
Effect of exposure to bull on post-partum reproductive aspects of Egyptian Baladi cattle:

Post-partum first service interval was significantly $(P<0.05)$ lower $(70.7 \pm 18.7 \mathrm{~d})$ in cows exposed to bull than those not exposed to bull $(85.8 \pm 10.4 \mathrm{~d})$ (Table 4$)$. The present result is in agreement with that reported by Shipka and Ellis (1999) and Mat (2013) who suggested that the interval from calving to first service post-partum was lower (75.7 and $57.5 \mathrm{~d}$ ) in cows exposed to bull than those not exposed to bull (88.9 and $63.8 \mathrm{~d}$ ), respectively. Similar trend was observed by Zaidi and Anwar (2018) who found that the interval from calving to first service post-partum was less (26.3 d) in Nili-Ravi buffaloes exposure to bull than control group $(40.0 \mathrm{~d})$.
} 


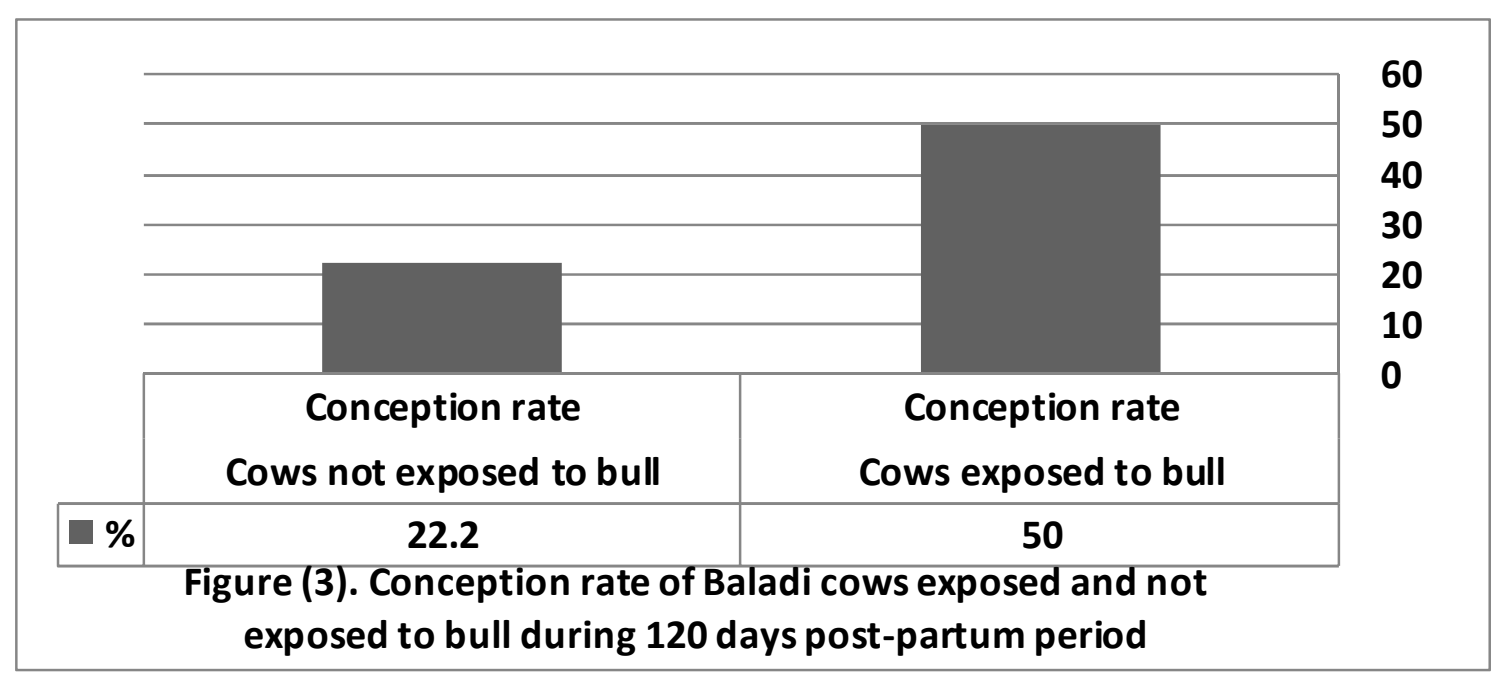

The interval from calving to conception (days open) was significantly $(P<0.05)$ lower $(91.7 \pm 18.5$ d) in cows exposure to bull than no-exposure to bull $(110.5 \pm 8.7 \mathrm{~d})$ (Table 4). The present result is in agreement with that reported by Soto Belloso et al. (1997) Shipka, and Ellis (1999) who found that the interval from calving to conception was tended to be less (73.0 and $114.1 \mathrm{~d}$ ) in cows after exposure to bull than no-exposure to bull (98.6 and $124.3 \mathrm{~d}$ ), respectively. Comparable trend, was observed by Gokuldas et al. (2010) who found that the interval from calving to conception was lower $(68.0 \mathrm{~d})$ in cows following exposed to bull compared with not exposed to bull $(81.2 \mathrm{~d})$.

Table 4. Effect of exposure to bull on post-partum reproductive aspects of Egyptian Baladi cattle during the experimental period

\begin{tabular}{lcc}
\multicolumn{1}{c}{ Items } & Exposure to bull & Non- exposure to bull \\
\hline No. of cases & 18 & 18 \\
Post-partum first service interval & $70.7 \pm 18.7^{\mathrm{a}}(9)$ & $85.8 \pm 10.4^{\mathrm{b}}(4)$ \\
Days Open & $91.7 \pm 18.5^{\mathrm{a}}$ & $110.5 \pm 8.7^{\mathrm{b}}$ \\
Number of service per conception & $1.8 \pm 0.4$ & $2.5 \pm 0.6$ \\
Conception rate $(\%)^{1}$ & $50^{\mathrm{a}}(9 / 18)$ & $22.2^{\mathrm{b}}(4 / 18)$ \\
\hline
\end{tabular}

$a, b$ : values within the same row having different superscripts are significantly different at $(P<0.05)$

1-Conception rate calculated during 120 days post-partum

Number of services per conception was lower ( $1.8 \pm 0.4$ service) in cows following exposure to bull than no-exposure to bull ( $2.5 \pm 0.6$ services). The difference between means was insignificant (Table 4). The present result is in agreement with that reported by Shipka and Ellis (1999) who found that number of services per conception tended to be less (1.9 service) in cows after exposure to bull post partum than no-exposure to bull (2.1 service). Similar trend, was reported by Silva Filho et al. (2015) who found that there was a positive effect of bio-stimulation on decreased the number of services per conception in beef cows.

Higher conception rate in cows that exposed to bull during the post-partum period $(50 \%)$ in contrast to cows no exposed to bull where less percentage was recorded $(22.2 \%)$. The difference between proportions was significant $(P<0.05)$ (Table 4$)$. The present result is in agreement with that reported by Ebert et al. (1972) and Shipka and Ellis (1999) who found that conception rate after first service was higher (68 and 53\%) in cows exposed to bull than in control cows (48 and 46\%) respectively. Comparable trend, was observed by Tauck and Berardinelli,
(2007) and Gokuldas et al. (2010) who reported that conception rate after first service was higher ( 85 and $54.5 \%$ ) in cows exposed to bull compared with in control group (60 and 15.5\%), respectively. Mat (2013) and Ungerfeld (2018) reported that conception rate after first service was higher (53.9 and 81\%) in cows following exposure to bull than in control group (18.2 and 58.6\%), respectively. Akhtar et al. (2015) obtained higher conception rate $(66.7 \%)$ in Cholistani cows that exposed to bull during post-partum compared to control cows $(33.3 \%)$. In addition, Silva Filho et al. (2015) suggested that the combination of bio-stimulation and temporary weaning led to increased pregnancy rate in beef cows.

\section{Effect of exposure to bull on estrous behavior of Egyptian Baladi cattle :}

Estrus signs under the experiment were more manifested in cows that exposed to bull compared to control group (Table 5). The difference between all signs in the two groups was insignificant. Table (5) shows that vaginal mucus discharge and mounting behavior were more frequent compared to signs in the control groups whereas the standing behavior was 
the same in both groups $(100 \%)$. The present observations were in agreement with those found by Landaeta-Hernández et al. (2008) and Mat (2013) who reported that cows exposed to bull during the post-partum period recorded higher percentage of estrus signs compared with control group. Comparable trend, was reported by Khanh et al. (2012) who found in primiparous cow more intense estrus and more mounting behavior (100\% vs. 52\%) when exposed to bull continuously. In addition, Zaidi and Anwar (2018) reported that the biostimulation by bull exposure for 24 hours daily led to a significantly higher estrus expression in Nili-Ravi buffaloes. The sexual behavioral of bull toward cows during the heat maybe due to pheromones that produced from cows in urine, faces, vaginal fluid (Sankar and Archunan, 2008, Sankar and Archunan, 2011 and Archunan and Kumar, 2012)

Table 5. Effect of exposure to bull on estrus behavior of Egyptian Baladi cattle during the experimental period

\begin{tabular}{lcc}
\hline \multicolumn{1}{c}{ Estrus signs } & \multicolumn{2}{c}{ Treatment } \\
\cline { 2 - 3 } & Exposure to bull & Non- exposure to bull \\
\hline No. of cases & 7 & 6 \\
Vaginal mucus discharge & $(5 / 7) 71.4$ & $(4 / 6) 66.7$ \\
Mounting behavior & $(6 / 7) 85.7$ & $(4 / 6) 66.7$ \\
Bellowing & $(4 / 7) 57.1$ & $(3 / 6) 50.0$ \\
Swelling of vulva & $(3 / 7) 42.9$ & $(3 / 6) 50.0$ \\
Standing behavior & $(7 / 7) 100$ & $(6 / 6) 100$ \\
\hline
\end{tabular}

Effect of exposure to bull on estrous cycle length (days) of Egyptian Baladi cattle:

The proportion of normal cycles recorded higher incidence $(71.4 \%)$ in cows exposed to bull during post-partum period compared with the control $(50 \%)$ (Table, 6). The odd cycles were less frequent in the two groups with no short cycles in cows exposed to bull. Similar trend was reported by LandaetaHernández et al. (2008) who showed that normal cycles were more frequent $(59.3 \%)$ in cows exposed to bull than $(50 \%)$ in cows not exposed in post- partum period. Hombuckle et al. (1995) reported that the percentages of normal cycles were significantly higher $(63 \%)$ in cows exposed to bull compared with (21\%) the control group. In addition, Smith et al. (1987) Garverick et al. (1992), and Breuel et al. (1993) reported that the biostimulation during early postpartum period maybe responsible for inducing the cows to resume ovarian activity with normal estrous cycles

Table 6. Effect of exposure to bull on estrus cycles length (days) of Egyptian Baladi cattle during the experimental period

\begin{tabular}{lccccccc}
\hline Estrous cycle & \multicolumn{7}{c}{ Treatment } \\
\cline { 2 - 7 } & \multicolumn{3}{c}{ Exposure to bull } & \multicolumn{4}{c}{ Non- exposure to bull } \\
\cline { 2 - 8 } & \multicolumn{7}{c}{ Types of estrous cycle length } \\
\cline { 2 - 8 } & Normal & Long & Short & Normal & Long & Short \\
& $18-24 \mathrm{~d}$ & $>24 \mathrm{~d}$ & $<18 \mathrm{~d}$ & $18-24 \mathrm{~d}$ & $>24 \mathrm{~d}$ & $<18 \mathrm{~d}$ \\
\hline No. of cycles & 5 & 2 & - & 3 & 2 & 1 \\
Percentage of cycles $\%$ & 71.4 & 28.6 & - & 50 & 33.3 & 16.7 \\
Mean \pm SE & $21.8 \pm 1.3$ & $32.5 \pm 0.7$ & - & $22.7 \pm 1.5$ & $33.5 \pm 2.1$ & $17.0 \pm 0.0$ \\
\hline
\end{tabular}

Effect of exposure to the bull on progesterone concentration $(\mathrm{ng} / \mathrm{ml})$ at estrus, seven, fourteen and twenty-one days post-estrus of Egyptian Baladi cattle:

Progesterone concentration throughout the estrous cycle in pregnant cows was slightly higher in treated cows compared to control group (Table 7). The present result is in agreement with the finding of Rekwot et al. (2000a) who found that the concentrations of progesterone was higher in cows exposed to bull but the difference was not significant. Comparable trend was also found by Custer et al. (1990) and Hombuckle et al. (1995) who reported that progesterone concentrations recorded higher value in cows that exposed to bull during the post- partum period. Fike et al. (1996) found that concentrations of progesterone were higher in cows following exposure to bull. In addition, Mate (2013) stated that secretion of progesterone in cows that exposed to the bull during the postpartum period had a more rapid rise after day 4 . Concentrations of progesterone were higher in pregnant cows at estrus compared with in non-pregnant however, the difference was insignificant (Table 7). Mate (2013) reported that higher concentrations of progesterone before mating maybe related to better conception rates. Dieleman et al. (1983) and Lonergan (2011) suggested that there was a relationship between progesterone and development of the dominant follicle and quality of oocyte. Folman et al. (1973) 
reported that higher concentration of plasma progesterone during the estrous cycle pre- insemination was related to incidence of conception in dairy cows.

Table 7. Effect of exposure to the bull on progesterone concentration (ng/ml) (Mean $\pm \mathrm{SE})$ at estrus, seven, fourteen and twenty-one days post-estrus of Egyptian Baladi cattle

\begin{tabular}{lcccc}
\hline Days of estrous cycle & \multicolumn{3}{c}{ Treatment } \\
\cline { 2 - 5 } & \multicolumn{2}{c}{ Exposure to bull } & \multicolumn{2}{c}{ Non- exposure to bull } \\
\cline { 2 - 5 } & Pregnant & Non-pregnant & Pregnant & Non-pregnant \\
\hline At estrus Mean \pm SE & $0.36 \pm 0.02$ & $0.24 \pm 0.02$ & $0.26 \pm 0.03$ & $0.23 \pm 0.02$ \\
7 day Mean \pm SE & $2.82 \pm 0.16$ & $2.21 \pm 0.10$ & $2.72 \pm 0.17$ & $2.85 \pm 0.22$ \\
$\mathbf{1 4}$ day Mean \pm SE & $3.79 \pm 0.72$ & $4.03 \pm 0.42$ & $3.66 \pm 0.18$ & $3.54 \pm 0.13$ \\
21 day Mean \pm SE & $5.84 \pm 0.61$ & $0.22 \pm 0.04$ & $5.72 \pm 0.41$ & $0.25 \pm 0.01$ \\
\hline
\end{tabular}

\section{CONCLUSION}

The results of this research elucidated the beneficial effect of presence of bull with cows during the post-partum period for enhancing resumption of ovarian activity and improving the reproductive aspects of Baladi cattle.

\section{REFERENCES}

Akhtar, M. S., S. I. Hussain, M. M. Ayaz, L. Lodhi, M. Ameen, S. Ullah, M.H. Lashari, A. A. Farooq and M. Akhtar, 2015. Effect of bull exposure on the post-partum reproductive efficiency in Cholistani cows. Kafkas Univ. Vet. Fak. Derg., 21 (1): 33-36.

Alberio, R.H., G. Schiersmann, N. Caron and J. Mestre, 1987. Effect of a teaser bull on ovarian and behavioural activity of suckling beef cows. Animal Reprod., Sci., 14, 263-268.

Archunan, G. and R. Kumar, 2012. 1-Iodoundecane, an estrus indicating urinary chemo signal in Bovine (Bos Taurus). Journal Veterinary Science and Technology, Page, 3-4.

Arthur, G. H., 1964. Method of rectal examination. Wright's Vet. Obs., 4: 71-80.

Berardinelli J.G and P.S. Joshi, 2005. Initiation of postpartum luteal function in primiparous restricted-suckled beef cows exposed to a bull or excretory products of bulls or cows. J Animal Sci., $83: 2495-2500$

Berardinelli, J.G. and S.A. Tauck, 2007. Intensity of the biostimulatory effect of bulls on resumption of ovulatory activity in primiparous, suckled, beef cows. Anim Reprod Sci 2007;99:24 -33.

Bolanios, J. M., M. Forsberg, H. Kindahl and H. Rodriguez-Martinez, 1998. Biostimulatory effects of estrous cows and bulls on resumption of ovarian activity in postpartum anestrous Zebu (Bos indicias) cows in the Humid tropics. Theriogenology, 49:629-636.

Breuel, K.F., P. E. Lewis, E.K Inskeep and R.L Butcher, 1993. Endocrine profiles and follicular development in early-weaned postpartum beef cows. J. Reprod. Fertil., 97: 205-212.
Burns, P.D. and J. C. Spitzer, 1992. Influence of biostimulation on reproduction in postpartum beef cows. J Animal Sci.,70:358-362.

Crowe, M.A., M.G. Diskin and E.J.,Williams, 2014. Parturition to resumption of ovarian cyclicity: comparative aspects of beef and dairy cows. J Animal, 8:40-53.

Custer, E.E., J.G. Berardinelli , R. E. Short, M. Wehrman and R. Adair, 1990. Postpartum interval to estrus and patterns of $\mathrm{LH}$ and progesterone in first-calf suckled beef cows exposed to mature bulls. J Anim Sci., 68:1370-1377.

Dieleman, S. J.,M .M. Bevers, J. Poortman, and H. T. M. Van Tol, 1983. Steroid and pituitary homone concentrations in the fluid of preovulatory bovine follicles relative to the peak of $\mathrm{LH}$ in the peripheral blood. Journal Reproduction Fertility, 69: 641-649.

Duncan, D. B., 1955. Multiple ranges and multiple F. Test. Biometrics, 11:1-24.

Ebert, J. J., P. Conteras and P. Saelzer, 1972. Influence of a teaser bull on puerperium and fertility in dairy cows. In: Proceedings of the $8^{\text {th }}$ International Congress on Animal Reproduction and Artificial Insemination, 3: 1743-1748.

Fernandez, D.L., J.G. Berardinelli, R.E. Short and R. Adair, 1996. Acute and chronic changes in luteinizing hormone secretion and postpartum interval to estrus in first-calf suckled beef cows exposed continuously or intermittently to mature bulls. J Animal Sci, 74:1098-1103.

Fernandez, D., J.G. Berardinelli, R. E. Short and R. Adair, 1993. The time required for the presence of bulls to alter the interval from parturition to resumption of ovarian activity and reproductive performance in first-calf suckled beef cows. Theriogenology, 39, 411-419.

Fike, K.E., E.G Bergfeld, A. S. Cupp, F.N. Kojima, V. Mariscal, T.S., Sanchez, J.E. Wehrman and J. E. Kinder, 1996. Influence of fenceline bull exposure on duration of postpartum anoestrous and pregnancy rate in beef cows. Animal Reprod. Sci., 41, 161-167.

Fiol, C. and R. Ungerfeld, 2016. Positive effects of biostimulation on $\mathrm{LH}$ concentration and follicular 
development in anestrous beef heifers. J Anim Sci, 94:1-7.

Folman, Y., M. Rosenberg, Z. Herz and M. Davidson, 1973. The relationship between plasma progesterone concentration and conception in postpartum dairy cows maintained on two levels of nutrition. J. Reprod. Fertil., 34: 267-278.

Garverick, H.A., W.G. Zollers and M.F. Smith, 1992 . Mechanisms associated with corpus luteum life span in animals having normal or subnormal luteal function. Animal Reprod. Sci., 28: 111-124.

Gokuldas, P.P., M.C. Yadav, H. Kumar, G. Singh, S. Mahmood and A.K.S Tomar, 2010. Resumption of ovarian cyclicity and fertility response in bull exposed postpartum buffaloes. Animal Reprod. Sci., 121: 236-241.

Hombuckle,T., R. S. Ott, M. W. Ohl, G. M. Zinn, P. G. Weston and J. E. Hixon,1995. Effects of bull exposure on the cyclic activity of Beef cows. Theriogenology, 43:411-418.

Kerketta, S., A. K. Singh, S. Sahu, D. Upadhyay, M. Abdullah, R. K. Yogi and M. Singh, 2017. Biostimulation- Innovative tool to improve reproductive efficiency in farm animals. International Journal of Livestock Research, 7 (4): 18-30.

Khanh, N.P., Y. Roshnina, M.S. Omar, G.K. Dhaliwal, H. Wahid, A.M. Khumran, K.C.Yap, Fahmi and A. Azmil, 2012. Effects of biostimulation on oestrus behaviour, ovulation time and conception rate in primiparous and multiparous Beef cows. Journal of Animal and Veterinary Advances, 11(3): 303-411.

Landaeta-Hernández, A. J., P. Meléndez, J. Bartolomé, D.O. Rae and L.F. Archbald, 2013. Effect of biostimulation and social organization on the interval from calving to resumption of ovarian cyclicity in postpartum Angus cows. Theriogenology, 79 : 1041-1044.

Landaeta-Hernández, A.J., P. Meléndez ,J. Bartolomé , D.O. Rae and L.F. Archbald, 2006. Effect of biostimulation on the expression of estrus in postpartum Angus cows. Theriogenology, 66:710716

Landaeta-Hernández, A. J., P. Meléndez, J. Bartolomé, O. R. Louis and L. F. Archbald. 2008. The effect of bull exposure on the early postpartum reproductive performance of suckling Angus cows. Revista Científica, 6: 682 - 691.

Lonergan, P., 2011. Influence of progesterone on oocyte quality and embryo development in cows. Theriogenology, 76(9):1594-601.

Mader, T. L., M.S. Davis, and T. Brown-Brandl, 2006. Environmental factors influencing heat stress in feedlot cattle. J. Anim. Sci., 84: 712-719.

Martin, G.B., 2009. The "Cleen, Green and Ethical" Concept in Animal Production. Agrociencia. XIII, $\mathrm{N}^{\mathrm{o}} 3,1-7$.

Martin, G.B., J.T.B. Milton, R.H. Davidson, G.E. Banchero Hunzicker, D.R. Lindsay, D. Blache, 2004. Natural methods for increasing reproductive efficiency in small ruminants. Animal Reprod. Sci., 82-83: 231-245.

Mat, K., 2013. Influence of Bull Exposure on Reproductive Performance of Postpartum Dairy Cows. PhD. Thesis, School of Agri., Newcastle Univ., UK.

Miller, V. and R. Ungerfeld, 2008. Weekly bull exchange shortens postpartum anestrous in suckled beef cows. Theriogenology, 69: 913-917.

Monje, A.R., , R.J. Alberio, G. Schiersmann, P.J. Chedrese and N. Carou, 1983. Effect of male presence on sexual activities and postcalving of breeding cows in two nutritional levels. Rev. Argentina Animal Prod. J., 4: 364-369.

Naasz, C.D. and H.L. Miller, 1990. Effects of bull exposure on postpartum interval and reproductive performance in beef cows. Can J Anim Sci., 70:537-542.

Naasz, C.D. and H.L Miller, 1987. Effects of bull exposure on postpartum interval and preproductive performance in beef cows. J. Animal Sci., 65 (Suppl.), 426 (abstract).

Rekwot, P. I.; D. Ogwu, E.O. Oyedipe and V.O. Sekoni, 2001. The role of pheromones and biostimulation in animal reproduction. Animal Reprod. Sci., 65: 157-170.

Rekwot, P.I., D. Ogwu, E.O. Oyedipe and V.O Sekoni, 2000a. Effects of bull exposure and body growth on onset of puberty in Bunaji and Friesian Bunaji heifers. Reprod. Nutr. Dev., 40: 359-367.

Rekwot, P.I., D. Ogwu and E.O. Oyedipe, 2000 b. The influence of bull biostimulation, season and parity on resumption of ovarian activity of Zebu (Bos indicus) cattle following parturition. Animal Reprod. Sci., 63: 1-11.

Sankar, R. and G. Archunan, 2008. Identification of putative pheromones in bovine (Bos taurus) faeces in relation to estrus detection. Animal Reprod. Sci., 103: 149-153.

Sankar, R. and G. Archunan, 2011. Gas chromatographic/mass spectrometric analysis of volatile metabolites in bovine vaginal fluid and assessment of Their Bioactivity International Journal of Analytical Chemistry. Volume 2011, Article ID, 256106,7pages.

SAS, 2002. User's Guide: Statistics, Version 9.0 Edition. SAS Institute Inc., Cary, NC, USA.

Shipka, M. P. and L.C. Ellis, 1998. No effects of bull exposure on expression of estrous behavior in high-producing dairy cows. Applied Animal Behaviour Sci., 57:1-7.

Shipka, M. P. and L.C. Ellis, 1999. Effects of bull exposure on postpartum ovarian activity of dairy cows. Animal Reprod. Sci., 54:237-244.

Silva Filho, M.L., L.R. Bezerra , J.C. Ferreira-Silva, F.M. Souto, N.R. Oliveira , P.F. Lima, C.C. Bartholomew, M.A.L. Oliveira, 2015. Influence of biostimulation and temporary weaning on follicular dynamics and pregnancy rates in Nelore cows (Bos taurus indicus). Trop Anim Health Prod., 47:1285-1291. 
Smith, V.G., J.R. Chenault, J.C. Mcallister, J.W. Lauderdale, 1987. Response of postpartum beef cows to exogenous progestogens and gonadotropin releasing hormone. J. Anim. Sci., 64: 540-551.

Soto-Belloso, E., L. Ramírez-Iglesias, L. Guevara, G. Soto-Castillo, 1997. Bull effect on the reproductive performance of mature and first calf suckled zebu cows in the tropics. Theriogenology, 48:1185-90.

Tauck, S. A., J. G. Berardinelli T. W. Geary N. J. Johnson, 2006. Resumption of postpartum luteal function of primiparous, suckled beef cows exposed continuously to bull urine. Journal of Animal Sci., 84: 2708-2713.

Tauck, S. A., J. R. Olsen, J. R. C. Wilkinson and J.G. Berardinelli, 2010. Duration of daily bull exposure on resumption of ovulatory activity in postpartum, primiparous, suckled, beef cows. Animal Reprod., Sci., 118: 13-18.
Tauck, S.A. and J.G. Berardinelli, 2007. Putative urinary pheromone of bulls involved with breeding performance of primiparous beef cows in a progestin-based estrous synchronization protocol. Journal of Animal Sci., 85: 1669-1674.

Ungerfeld, R., 2018. Biostimulation in primiparous postpartum acyclic early-weaned beef cows: introducing the bulls at weaning advances cyclic rebreeding. Animal Reprod., 15 (4):.1205-1207.

Zaidi, N.S. and M. Anwar, 2018. Effect of biostimulation on estrus expression, resumption of ovarian activity and conception rate in postpartum anestrus Nili-Ravi buffaloes during low breeding season. Pak Vet J, 38(1): 35-38.

Zalesky, D.D., M.L. Day, M .Garcia Winder, K. Imakawa, R.J. Kittok, M.J. Docchio, J.E. Kinder, 1984. Influence of exposure to bulls on resumption of estrous cycles following parturition in beef cows. J Anim Sci., 59:135-9.

تأثير التبييه الحيوي باستخدام التعرض للأكر على إستعادة النشاط المبيضى والمظاهر التناسلية خلال فترة ما بعد

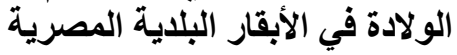

أحمد إسماعيل ضمرانى

قسم الإنتاج الحيوانس، كلية الزراعة والموارد الطبيعية، جامعة أسوان، مصر

هدفت الدراسة الحالية إلى تقييم تأثير التنتيه الحيوي على استعادة النشاط المبيضى و الدظاهر التناسلية في الأبقار البلدية بعد الو لادة. أستخدم

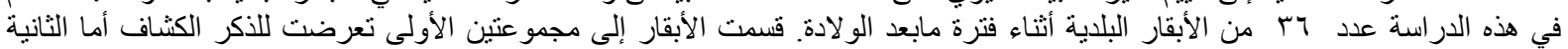

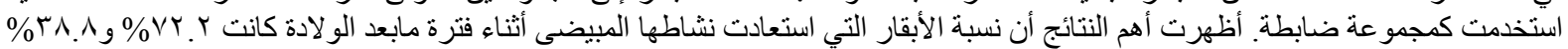

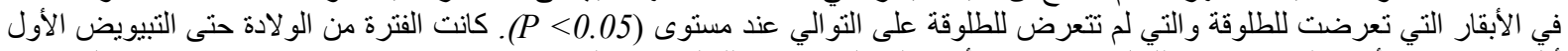

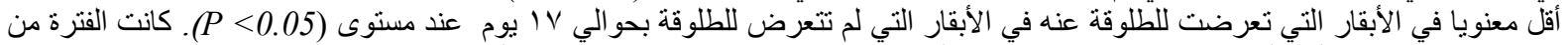

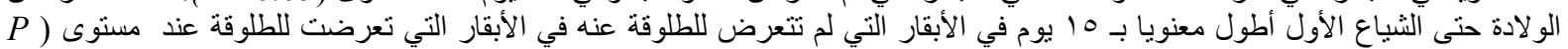

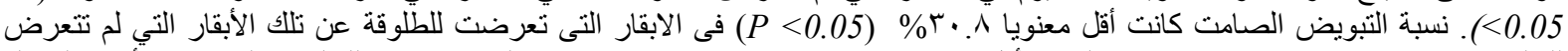

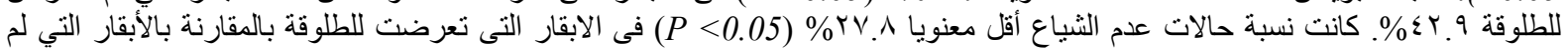

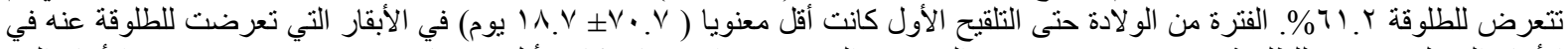

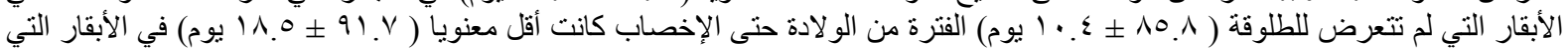

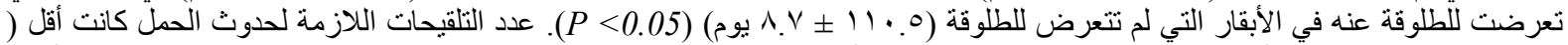

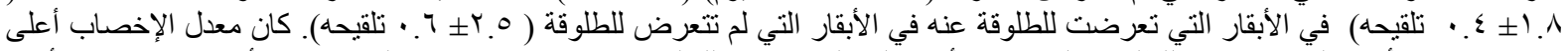

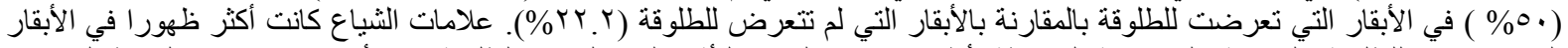

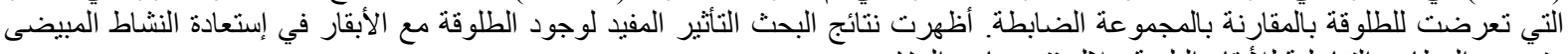
وتحسين المظاهر التناسلية للأبقار البلاية خلال فترة مابعد الولادة. 